\title{
COPROLITES FROM CALVERT CLIFFS: MIOCENE FECAL PELLETS AND BURROWED CROCODILIAN DROPPINGS FROM THE CHESAPEAKE GROUP OF MARYLAND, U.S.A.
}

\author{
STEPHEN J. GODFREY ${ }^{1,2, *}$, ALBERTO COLLARETA ${ }^{3,4} \&$ JOHN R. NANCE $^{1}$
}

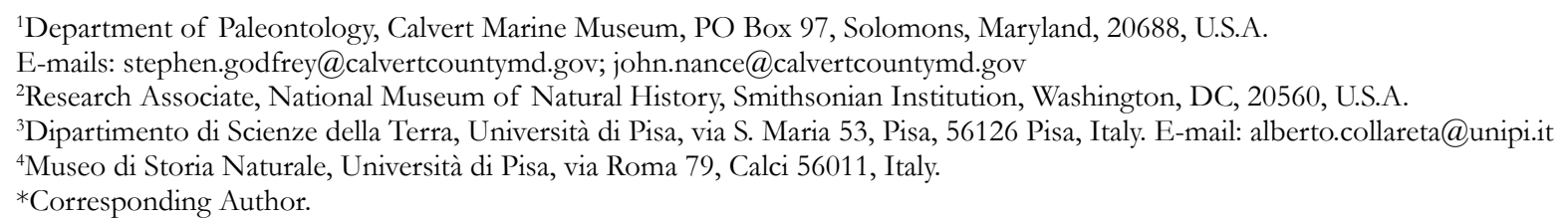

Associate Editor: Lorenzo Rook

To cite this article: Godfrey S.J., Collareta A. \& Nance J.R. (2022) - Coprolites from Calvert Cliffs: Miocene fecal pellets and burrowed crocodilian droppings from the Chesapeake Group of Maryland, U.S.A. Riv. It. Paleontol. Strat., 128(1): 69-79.

Keywords: Micro-coprolites; Coprulus; Annelida; Thecachampsa; St. Marys Formation; Calvert Formation.

\begin{abstract}
New finds of remarkable coprolites (fossilized feces) are here reported from the famous Miocene marine sediments of the Chesapeake Group exposed along Calvert Cliffs (Maryland, U.S.A.).

Although vertebrate coprolites have been described from these deposits, here we provide the first description of tiny invertebrate fecal pellets. Thus far, these fecal pellets have only been found in the upper Miocene (Tortonian) St. Marys Formation. The micro-coprolites represent the coprulid ichnospecies Coprulus oblongus. The fecal pellets are found in small clusters or strings of dozens to masses of many hundreds. Pellets range in size from approximately $0.4-2.0 \mathrm{~mm}$ wide by $1.0-5.0 \mathrm{~mm}$ long, and range in color from gray to brownish black. Their length/diameter ratio is always very nearly 2 . These coprulids have been found in a variety of Miocene fossils/concretions including a uranoscopid neurocranium, naticid gastropod, bivalve shells, barnacle tests, and in pellet-backfilled sinuous burrows through sediment. Because the fecal pellets are often found in tiny spaces or spaces thought to be inaccessible to shelled invertebrates, the coprulids are attributed to small and soft-bodied polychaetes or other annelids.

Some coprolites attributed to crocodilians from the lower-middle Miocene Calvert Formation were tunneled into, presumably the result of coprophagy, by some unknown kind of organism(s). These complex trace fossils are in the form of burrows that excavate the coprolites, the sides of which are sculptured by scratch/gouge marks.
\end{abstract}

\section{INTRODUCTION}

A variety of coprolites (fossilized feces) have been described from the Cenozoic deposits from along the coastal bluffs and cliffs of southern Maryland, U.S.A. (Wetmore 1943; Godfrey \& Smith 2010; Weems 2018; Godfrey et al. 2020). These are mostly recognizable as the phosphatized droppings of marine vertebrates and include uncommon finds such as fish-bitten coprolites (Godfrey \& Smith 2010; Godfrey et al. 2020). By describing other remarkable coprolite occurrences from the famous Miocene marine sediments of the Chesapeake Group exposed along Calvert Cliffs, the present paper aims to enhance our knowledge of the conspicuous coprofauna of southern Maryland.

Historically, invertebrate coprolites have not received the same attention as those of vertebrates (Häntzschel et al. 1968; Knaust 2020). That is be- 


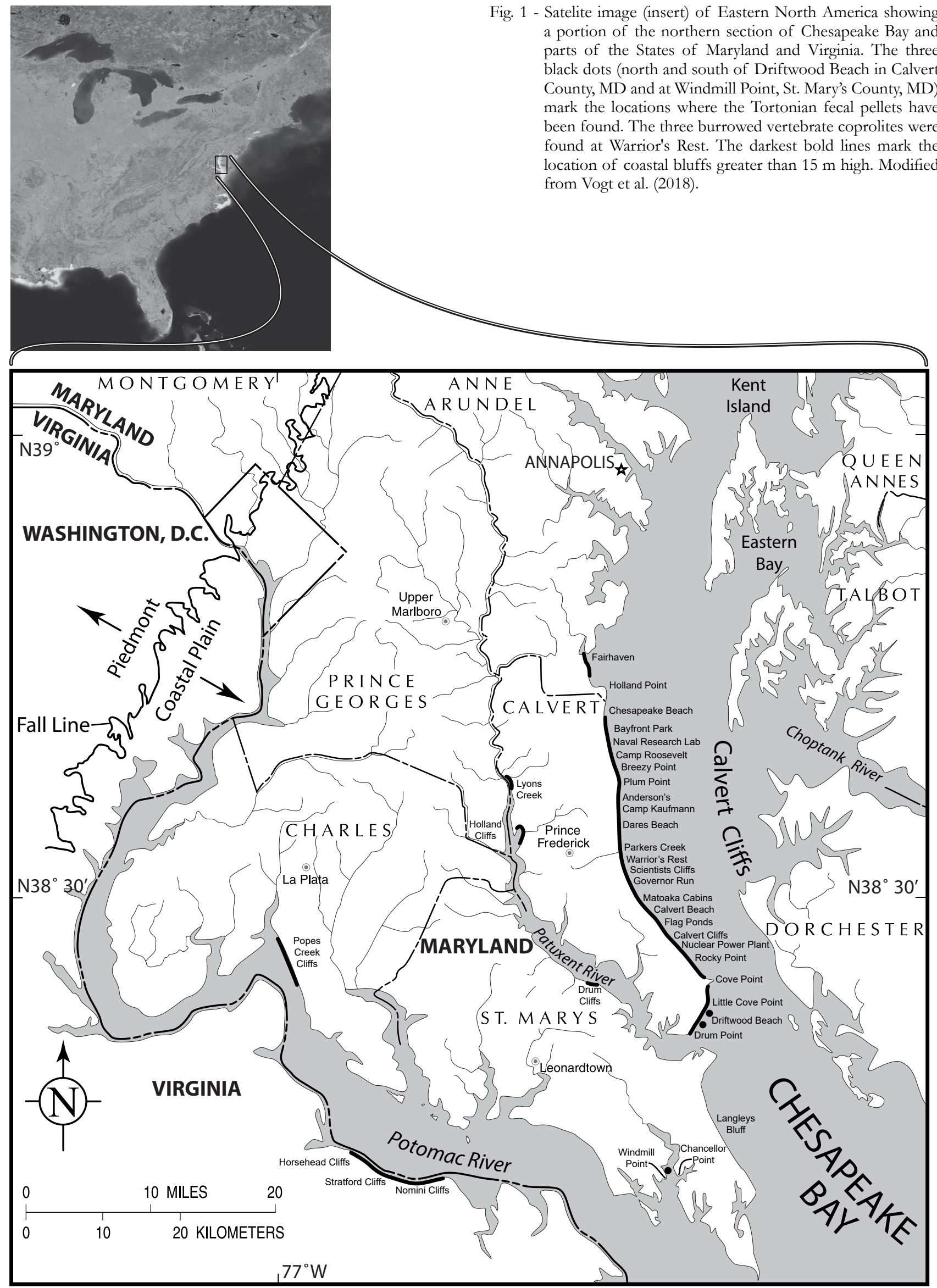


ginning to change as evidenced by the recent work by Knaust (2020), and the many references therein. Here, we describe the tiny fecal pellets (coprulids) of one or more kinds of invertebrate that have been found with increasing regularity in the Tortonian St. Marys Formation along Calvert Cliffs. Carnevale et al. (2011) recorded that the paratype of Astroscopus countermani (CMM-V-2022), a fish neurocranium lacking most of the orbital region and part of the right otic region, was nearly completely infilled with oblong fecal pellets, possibly produced by crustaceans. They did not describe these fecal pellets, nor describe their widespread preservation within a variety of concretions within the St. Marys Formation. That is our intent here. Other coprolites from Calvert Cliffs, conforming in size and overall shape to vertebrate producers, display tunneling penetrating deep into the fecal mass. These centimeter-sized cylindrical tunnels constitute complex trace fossils - that is, traces that exploit other ichnofossils as their substrate. A literature survey reveals that only a few other similarly tunneled coprolites seem to exist worldwide. Here, these remarkable finds are also described and figured, and some hypotheses about their origin are also discussed.

\section{GeOlogic SETTING}

The Miocene deposits of the Atlantic Coastal Plain of North America include the siliciclastic sediments of the Calvert and St. Marys formations. These fossiliferous shallow marine deposits comprise the lower and uppermost portion, respectively, of the Neogene Chesapeake Group as exposed in the Calvert Cliffs and surrounding area along the Chesapeake Bay shoreline in Calvert County and the St. Mary's River in St. Mary's County (Fig. 1) (Shattuck 1904; Kidwell 1984; Kidwell et al. 2015; Vogt et al. 2018). The deposits comprising both formations are located along the western margin of the Salisbury Embayment, a paleogeographic domain that was occupied by a shallow arm of the Atlantic Ocean during the Miocene (Ward \& Andrews 2008), structurally representing a westward extension of the Baltimore Canyon Trough (Poag 1979; Kidwell 1984; Kidwell et al. 2015). Overall, the Miocene succession of the Chesapeake Group records a gradual shallowing within the Salisbury Embayment (e.g. Kidwell 1984, 1988, 1989, 1997; Ward \& Strickland
1985; Ward 1992; Ward \& Andrews 2008). The lower-middle Miocene Calvert Formation is comprised of fully marine, inner to middle shelf deposits alternating with dense shelly sands of shoreface to inner shelf depths, whereas deposition of the St. Marys reflects a transition from an open marine shelf to tidally influenced lower salinity muddy coastal embayments (Kidwell et al. 2015; Godfrey \& Carnevale 2020). The burrowed coprolites described in the present paper come from the Plum Point Member, whose chronostratigraphic range spans the upper Burdigalian and most of the Langhian (Vogt et al. 2018, and references therein). Sediments comprising the members of the St. Marys Formation (in ascending order, the Little Cove Point and Windmill Point members) show rapid lateral and vertical facies changes (Kidwell 1988, 1997; Kidwell et al. 2015). The micro-coprolites described herein derive from both the Little Cove Point and the Windmill Point members and together are estimated to range in age from 7.5 to $10.5 \mathrm{Ma}$ (Perez et al. 2019, fig. 1).

Both the Calvert and the St. Marys formations have yielded a rich record of marine and terrestrial organisms (Vogt \& Eshelman 1987; Carnevale \& Godfrey 2018; Godfrey 2018). A large number of predominantly marine species have been described from these deposits, with representatives from several groups of microfossils and invertebrates (de Verteuil \& Norris 1996; Vokes 1957 [1968 reprint]; Ward 1992), as well as of an array of vertebrate taxa, including sharks and rays, actinopterygian fishes, turtles, crocodiles, pelagic birds, seals, sea cows, odontocete and mysticete cetaceans, and rare isolated remains of large terrestrial mammals (e.g., Clark et al. 1904; Ward \& Andrews 2008; Carnevale et al. 2011; Weems \& George 2013; Domning 2018; Godfrey 2018; Kent 2018; Weems 2018; Godfrey \& Carnevale 2020).

\section{MATERIAL AND METHODS}

All the known micro-coprolite specimens were collected as float from the beaches surrounding Driftwood Beach (within the Chesapeake Ranch Estates community) along Calvert Cliffs, Calvert County, Maryland, U.S.A. (Little Cove Point Member of the St. Marys Formation) or from Windmill Point, St. Mary's County, Maryland, U.S.A. (Little Cove Point and Windmill Point members of the St. 
Marys Formation), (Fig. 1). Approximate geographic coordinates for the collection area north of Driftwood Beach are N38 21'16.94”, W76²3'31.50", and for Windmill Point, they are N38 $09^{\prime} 52.68^{\prime \prime}$, W76 $27^{\circ} 25.27^{\prime \prime}$.

The three burrowed vertebrate coprolites were collected from the Plum Point Member of the Calvert Formation at Warrior's Rest, Calvert Cliffs. Approximate geographic coordinates for these coprolites are N38'31'43.83', W76³0'56.13'".

All the specimens described herein are stored at the Calvert Marine Museum (= CMM), Solomons, Maryland, either in the invertebrate paleontology (= CMM-I) or in the vertebrate paleontology $(=\mathrm{CMM}-\mathrm{V})$ collections.

\section{Specimens Examined}

CMM-I-3712, a single concretion preserving fecal pellets in a sinuous burrow (Fig. 4B), collected from north of Driftwood Beach by J. Nance; CMM-I-3713, consisting of two specimens, one of several dozen fecal pellets in a concretion and the second of dozens of pellets in a naticid gastropod (Fig. 4A), collected from North of Driftwood Beach by J. Nance; CMM-I-3950, a single concretion preserving many fecal pellets, collected at Windmill Point by J. Nance; CMM-I-4193, including two specimens, one of which preserves several hundred fecal pellets, collected at Windmill Point by J. Nance; CMM-I-4248, consisting of seven concretions preserving many dozens of fecal pellets, (one of which is figured here, Fig. 2A), collected at Windmill Point by J. Nance; CMM-I-4251, consisting of four concretions preserving dozens to over a hundred fecal pellets, collected from north of the Driftwood Beach parking lot, Chesapeake Ranch Estates by J. Nance; CMM-I-4277, consisting of twenty eight concretions each one preserving dozens of fecal pellets (two of which are figured here, Fig. 3B and 3C-D), collected from north of the Driftwood Beach parking lot by J. Nance; CMM-I-4321 (Fig. 4C-D), fecal pellets found in and around Miocene (concavine?) barnacle tests attached to a scallop partial shell, collected from North of Driftwood Beach by J. Nance; CMM-I-4457, consisting of a single concretion preserving 13 fecal pellets, collected from north of Driftwood Beach by J. Nance; CMM-I-4572, consisting of eight concretions preserving many dozens of fecal pellets (one of which is figured here, Fig. 2E), collected at Windmill Point by J. Nance; CMM-I-4745 (Fig. 2F), a single concretion preserving many dozens of fecal pellets, collected at Windmill Point by W. Johns; CMM-V-2022 (Fig. 3B-D), fecal pellet-infilled neurocranium of Astroscopus countermani (Carnevale et al. 2011: fig. 4), collected from south of Driftwood Beach parking lot by the late J. Hooper; CMM-V-3407, a single concretion preserving dozens of fecal pellets, collected from north of Driftwood Beach parking lot by W. (Bill) Counterman; CMM-V-5805, a burrowed vertebrate coprolite, collected from Shattuck Zone 14 at Warrior's Rest, Calvert Cliffs by M. Ellwood; CMM-V-6500, a burrowed vertebrate coprolite, collected at Warrior's Rest, Calvert Cliffs by M. Ellwood; CMM-V-6524, a single concretion preserving several dozen fecal pellets, collected at Windmill Point by W. Johns; CMM-V-7958, a burrowed vertebrate coprolite, collected at Warrior's Rest by P. Murdoch.

\section{Imaging and Chemical Elemental Analyses}

Scanning electron microscopy (SEM) images were taken at the SEM Lab of the National Museum of Natural History (Smithsonian Institution) Washington, DC, U.S.A. For the micro-coprolites, chemical elemental analyses were performed using a FEI QUANTA 450 ESEM-FEG equipped with an electron dispersive spectroscopy (EDS) Bruker's QUANTAX XFlash Detector 6|10 at the Centro per la Integrazione della Strumentazione dell'Università di Pisa (CISUP), Pisa, Italy.

To improve contrast and highlight detail in Figure 3B-D, CMM-V-2022 was dusted with sublimed ammonium chloride (a whitening technique described by Cooper, 1935 and Feldman, 1989). After the specimen was photographed, the ammonium chloride was removed by holding the specimen under running water (Shelburne \& Thompson, 2016).

Specimens included in Figures 2, 3B-E, 4, and 5 were photographed using a Nikon CoolPix P510 camera. The specimens were photographed on a black velvet background under fluorescent lighting.

\section{RESULTS AND DESCRIPTION}

All the fecal pellets from the St. Marys Formation are remarkably uniform in their oblong/ellipsoidal shape (Figs. 2-4). They range in size from approximately $0.4-2.0 \mathrm{~mm}$ wide by $1.0-5.0 \mathrm{~mm}$ 
Fig. 2 - Coprulus oblongus. Miocene Tortonian fecal pellets in a variety of concretions.

A) CMM-I-4248.

B) CMM-I-4277.

C) CMM-I-4277, fecal pellet side of the concretion (steinkern).

D) CMM-I-4277, bivalve shell side of the same concretion as shown in $(\mathrm{C})$.

E) CMM-I-4572, steinkern showing some of the outer white shell of the bivalve.

F) CMM-V-4745.

White scale bars equal 10 mm.

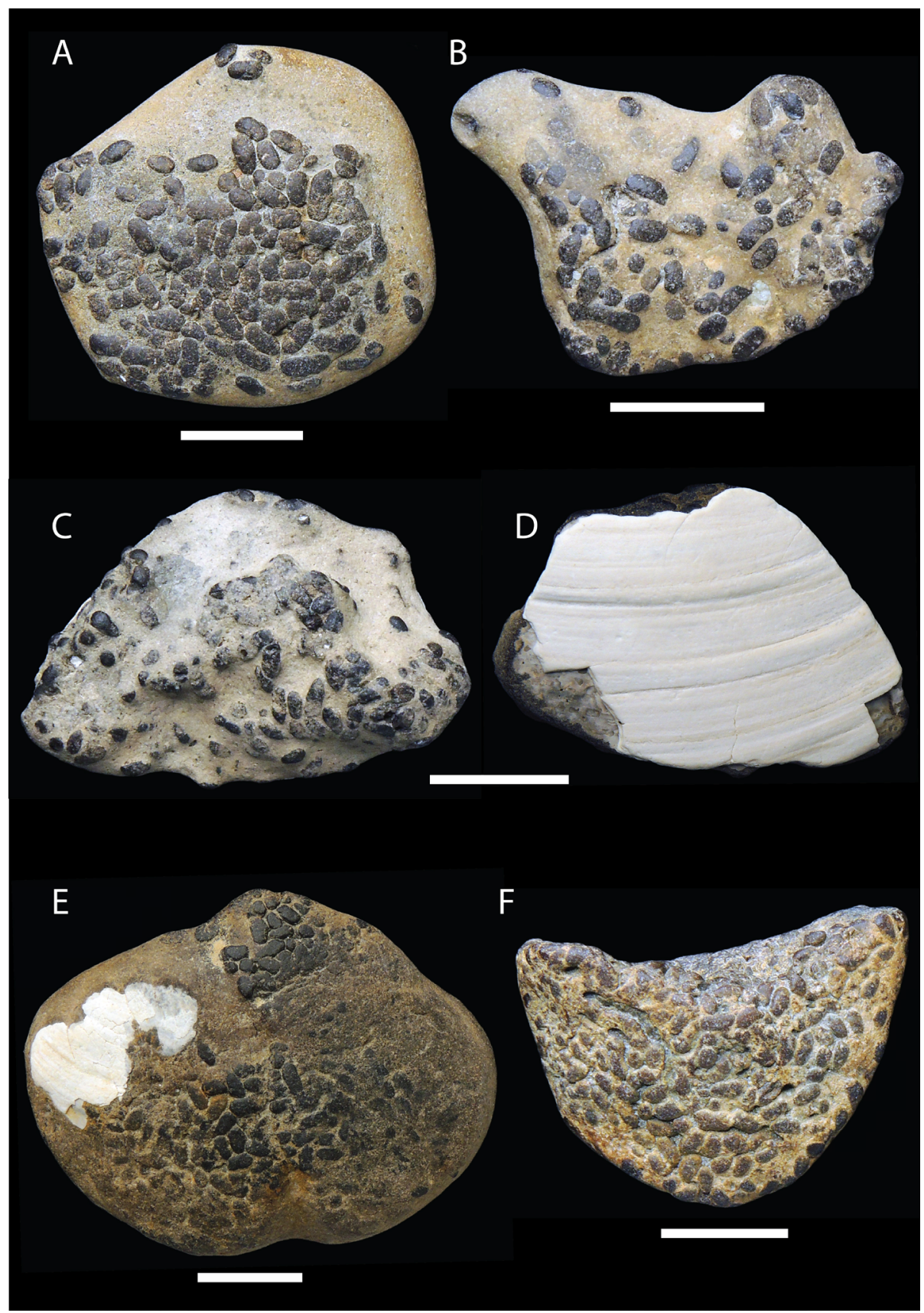

long. Their length/diameter ratio is always very nearly 2 . They range in color from gray to brownish black (Fig. 2). These fecal pellets are without internal structure and ornamentation and clearly derive from the ichnofamily Coprulidae (Knaust 2008, 2020). They all conform to the distinctive morphological characters of Coprulus oblongus; pellets with an essentially smooth surface, cylindrical to oval in shape and having a length/diameter ratio commonly between 1.5 and 2.0 (Knaust 2008; Toom et al. 2020).

Most of the pellets were found in concreted sediment (unusual for along Calvert Cliffs and at Windmill Point), many of which are steinkerns, as evidenced by the presence of the original mollusk shell on one side of the concretion (Fig. 2C-D and Fig. 2E). The fecal pellets are loosely scattered about in the concreted sediment or tightly clustered together (Fig. 2E, 3, and 4). In none of the specimens did the pellets seemingly display a preferred directional orientation.

Chemical analyses of three fecal pellets from CMM-I-4457 revealed an impure Ca-phosphatic composition (Table 1). Although C. oblongus was reported as having a calcitic composition by Knaust (2020), silicification or phosphatization of fecal pellets can take place during early diagenesis, 

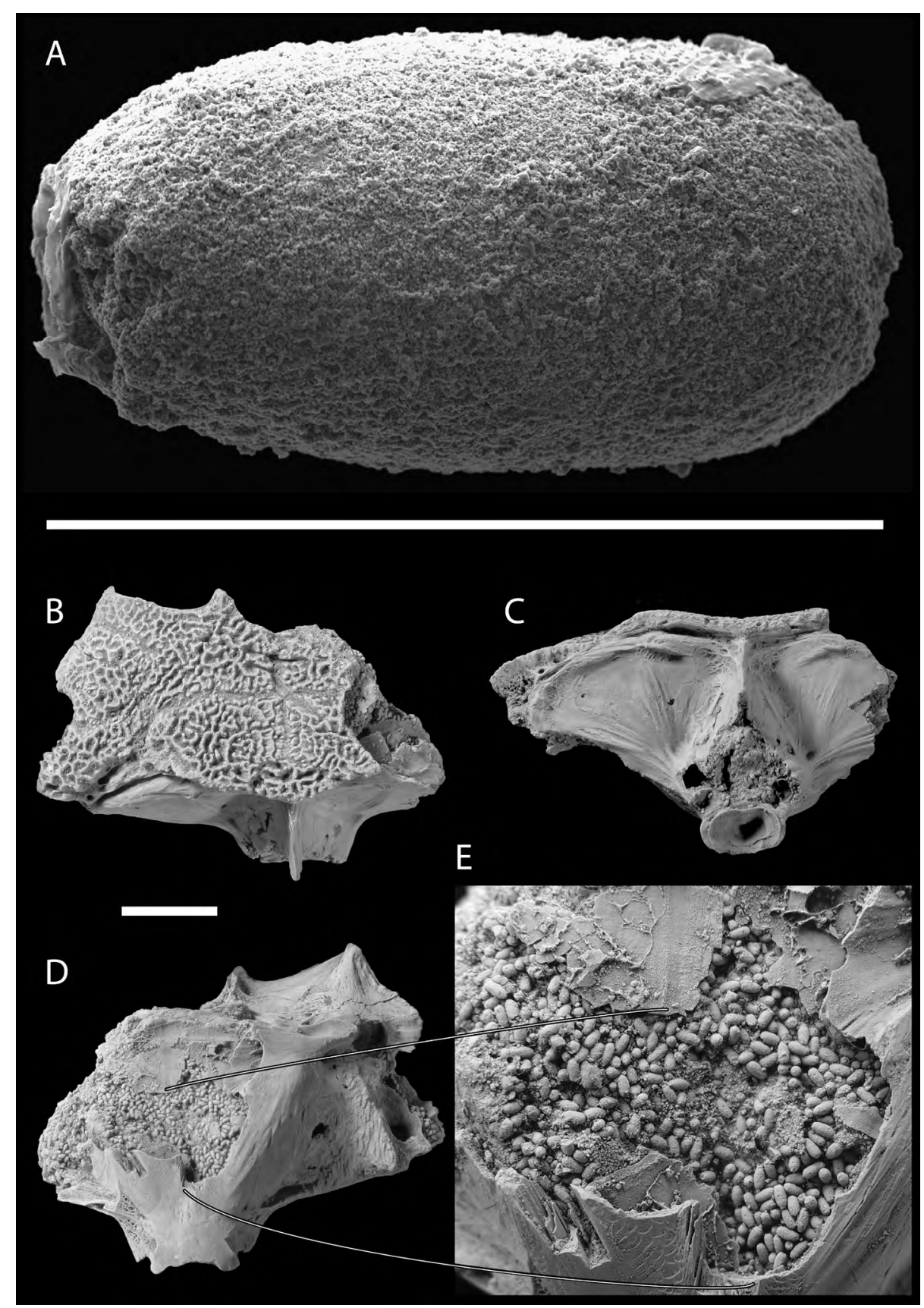

Fig. 3 - Coprulus oblongus.

A) A scanning electron micrograph of a single fecal pellet from CMM-V-2022. White scale bar equals 1 $\mathrm{mm}$.

B-D) CMM-V-2022, fecal pellet-infilled neurocranium of Astroscopus countermani (Carnevale et al. 2011: fig. 4) in dorsal, posterior, and ventral views respectively.

E) Enlarged view of (D) showing the densely packed fecal pellets within the neurocranium of CMM-V-2022. CMM-V-2022 whitened with sublimed ammonium chloride to improve contrast and highlight detail.

White scale bar for B-D equals $10 \mathrm{~mm}$. resulting in a different mineralogical composition (Bruthansová \& Kraft 2003). Considering that, as many other coprulid occurrences from the St. Marys Formation, the analyzed fecal pellets are entombed within a concretion, and the latter is also rather Caand P-rich (Table 1), we regard their chemical composition as likely due to secondary phosphatization, and as such, not ichnotaxonomically significant nor paleodietarily informative.

As for the burrowed vertebrate coprolites from the Calvert Formation, CMM-V-5805 is a fairly large specimen with a maximum length of $178 \mathrm{~mm}$ (Fig. 5). Its long axis is bent to an angle of about
90 degrees. The surface opening is subcircular in outline and approximately $15 \mathrm{~mm}$ in diameter (part of the perimeter of the outer opening was damaged and lost). Within the coprolite, the burrows range in diameter from 13 to $17 \mathrm{~mm}$. The walls of the cylindrical burrows are pervasively marked by many short burrowing/feeding gouges with no apparent preferred orientation. The same kinds of gouge markings are scattered about on the outer surface of this coprolite, a surface characteristic of most of the vertebrate coprolites from Calvert Cliffs (SJG pers. obs.). Within the coprolite, the tunnels curve and branch. 
Fig. 4 - Coprulus oblongus.

A) CMM-I-3713, fecal pellets partially infilling a Miocene naticid gastropod.

B) CMM-I-2712, fecal pellets backfilling a sinuous burrow.

C) CMM-I-4321, fecal pellets found in and around Miocene (concavine?) barnacle tests attached to a partial Miocene scallop shell.

D) A close-up view into one of the barnacle tests showing the cluster of many dozens of coprulids.

Scale bar for A, B, and D equals $10 \mathrm{~mm}$. Scale bar for C equals $50 \mathrm{~mm}$.

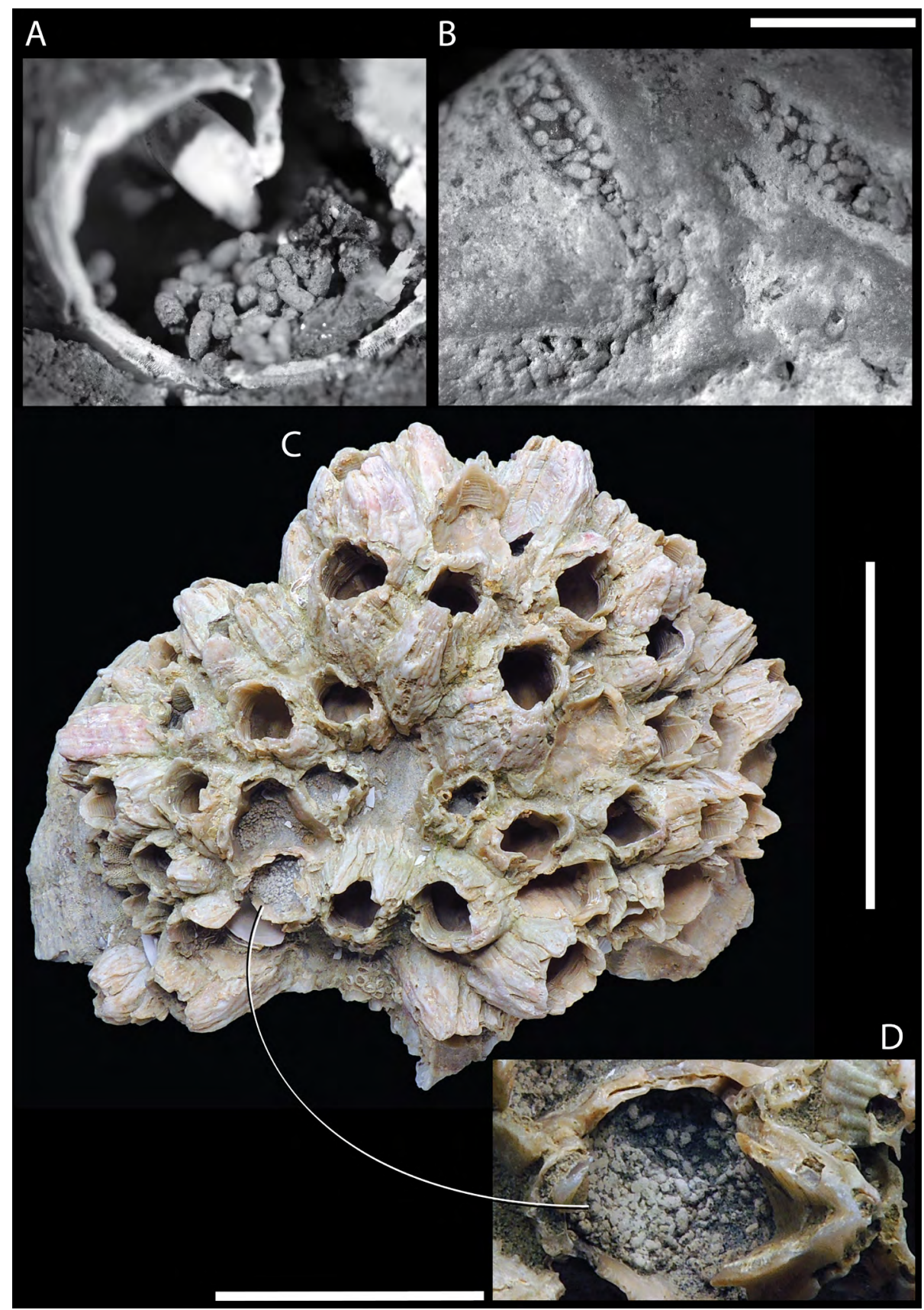

\section{Discussion}

Micro-coprolites: tracemaker(s) and paleoethological significance

Miocene Coprulus oblongus pellets from the St. Marys Formation have been found in a fish neurocranium, bivalve shells, a naticid gastropod shell, in and around barnacle tests, and in sediment in clusters or filling sinuous burrows. Although CMM-V-2022 (Fig. 3B-D, the fecal pellet-infilled neurocranium of Astroscopus countermani Carnevale et al., 2011: fig. 4), is the first fossilized vertebrate braincase known to be infilled with feces, it is not the first-known animal to have that distinction. Bruthansová \& Kraft (2003; ex. their fig. 3) described virtually identical clusters of pellets infilling the cephalon of Ordovician trilobites. Reminiscent of our pellet-filled mollusc shells (Figs. 2C-D, 4A) and barnacle tests (Fig. 4C-D), Bruthansová \& Kraft (2003: fig. 5) and Toom et al. (2020: figs. 3 and 4) figured accumulations of coprulid coprolites filling Ordovician shelly fossils such as echinoderms, molluscs (both cephalopods and gastropods), and brachiopods. Regardless of the identity of the pellet-maker, these finds seemingly testify to the persistence of a very ancient be- 


\begin{tabular}{|l|r|r|r|r|}
\hline & pellet \#1 & pellet \#2 & pellet \#3 & $\begin{array}{l}\text { entombing } \\
\text { concretion }\end{array}$ \\
\hline $\mathrm{Na}_{2} \mathrm{O}$ & 0.55 & 0.72 & 0.67 & 0.51 \\
\hline $\mathrm{MgO}$ & 0.89 & 0.79 & 1.22 & 0.54 \\
\hline $\mathrm{Al}_{2} \mathrm{O}_{3}$ & 1.51 & 3.49 & 3.47 & 2.82 \\
\hline $\mathrm{SiO}_{2}$ & 5.43 & 11.19 & 9.11 & 26.45 \\
\hline $\mathrm{P}_{2} \mathrm{O}_{5}$ & 24.84 & 24.71 & 22.72 & 19.00 \\
\hline $\mathrm{SO}_{3}$ & 4.38 & 3.67 & 4.79 & 2.98 \\
\hline $\mathrm{CaO}$ & 49.23 & 48.97 & 48.18 & 41.06 \\
\hline $\mathrm{FeO}$ & 2.16 & 3.43 & 4.41 & 2.71 \\
\hline total & 88.99 & 96.98 & 94.58 & 96.06 \\
\hline
\end{tabular}

Tab. 1 - Chemical composition (oxide wt $\%$ ) of three fecal pellets and the entombing concretion from sample CMM-I-4457 (oxide concentrations were not normalized to 100\%). Analyses by electron dispersive spectroscopy (see the main text for methodological details).

havioral pattern. According to Toom et al. (2019), some of such pellet accumulations in shelly fossils may represent an as yet undescribed ichnogenus. Coprulids filling burrows (Fig. 4B) and pellet trails are more abundantly known from the fossil record (often under the ichnogeneric names Tomaculum, Tubotomaculum and Tubularina, all of which are complex trace fossils; Knaust 2020) and their extant counterparts are also known (e.g., Kuo \& Bolton 2013: fig. 3).

Although there might be some question as to whether the pellets found in the bivalves or naticid gastropod shell were produced by those animals, there can be no doubt that the pellets infilling the neurocranium of Astroscopus were not produced by that fish. From the review of invertebrate coprolites given by Knaust (2020), these tiny fecal pellets give every indication that they are invertebrate coprolites, a conclusion based on their small size and abundance. "Abundance, [...] simply because many vertebrate droppings result from few individuals, whereas invertebrate faecal pellets may result from high population density and production." (Knaust 2020; p. 387). The ichnofamily Coprulidae, to which the tiny pellets described here belong, is known to range from the Cambrian to the Holocene. They are commonly produced by polychaetes and other annelids, enteropneusts, gastropods, bivalves, tunicates and insects (Knaust 2020: fig. 1). From the formation and depostional environment in which these fecal pellets were produced, we can safely rule out terrestrial insects as the producers. Because tunicates (i.e., sea squirts), are a group of marine animals that mostly spend their adult lives as sessile animals attached to rocks, this group can also probably be ruled out, at least in the case of those fecal pellets found within mollusk shells and the uranoscopid neurocranium. Enteropneusts are mostly depositiovorus, albeit at least some of them are filter feeders (Cameron 2002); observations on the infaunal, deposit feeding enteropneusts suggest that they defecate outside their burrows (Urata et al. 2012), so they too can probably be ruled out as the producers of the fecal pellets. That the coprulids are found in very tight quarters, like the innermost parts of a small fish neurocranium, or the inner whorls of a gastropod shell, suggests a soft-bodied invertebrate capable of squeezing into restricted spaces. This would probably then rule out gastropods and bivalves, leaving polychaetes and other annelids as the most likely candidate.

The apparent absence of these coprulids from the very fossiliferous Calvert and Choptank formations would suggest that the organism(s) producing these fecal pellets may have favored a more shallow-water near-shore marine environment as represented by the St. Marys Formation.

Origin of the burrowed vertebrate coprolites

From their large size and shape, vertebrate coprolites like CMM-V-5805 (Fig. 5), -6500, and -7958 are of the type attributed to crocodilians (Weems 2018: fig. 4.13D). The most likely producer of these fossilized feces is the Miocene tomistomine gavialid Thecachampsa, whose skeletal remains are found in Calvert Formation strata (Weems 2018).

The kind of wide tunneling that characterizes CMM-V-5805, -6500 and -7958 has been very rarely reported from coprolites. Similar centimeter-sized burrows have been found excavating herbivorous dinosaur coprolites from Cretaceous continental strata of Montana, U.S.A. (Chin \& Gill 1996; Chin 2007). In this nonmarine setting, dung beetles have been evoked as likely tunnelers (Chin \& Gill 1996). Marine bivalves are also known as producers of Gastrochaenolites burrows in coprolites (Tapanila et al. 2004), but the diameter of such burrows characteristically increases inward (Milàn et al. 2012), whereas the tunneling within CMM-V-5805 shows a remarkably constant diameter throughout. Hunt et 
Fig. 5 - CMM-V-5805, a burrowed crocodilian coprolite from Shattuck Zone 14 of the Plum Point Member of the Calvert Formation, Calvert Cliffs, Maryland, U.S.A.

A) General overview of the specimen, showing the circular opening through which the coprolite was burrowed. B) The coprolite opened up along the crack seen in (A), showing the interconncted cyindrical burrows within the coprolite. Notice the linear striations on the walls of the burrows. Scale bar equals $5 \mathrm{~cm}$.

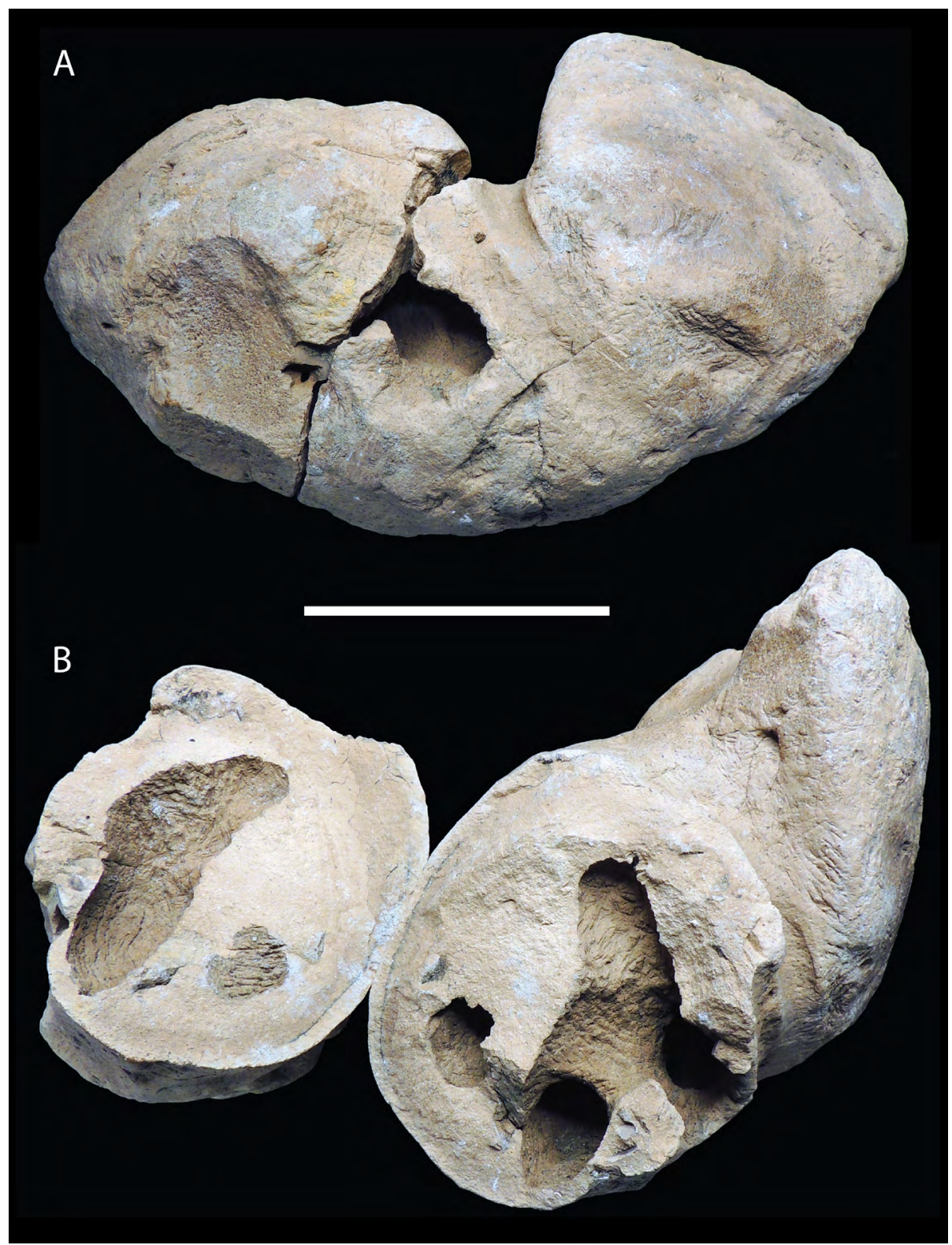

al. (2018) reported smaller-diameter (0.1-0.2 mm) burrows in Devonian coprolites (Gaspeichnus, a sinuous coprolite tunneling). Milàn et al. (2012: fig. 5) also figured modern droppings of the living dwarf crocodile (Osteolaemus tetraspis) exhibiting rounded pits and elongated scrapes over the feces' surface as well as deep tunnels into the fecal mass. All these features were attributed to the feeding action of coprophagous fly larvae (Milàn et al. 2012).

In conclusion, we do not know what kind of organism(s) tunneled into these coprolites and neither do we know for sure if these burrows were the result of feeding or the manufacturing of a living space (or both). However, when considering the gouge marks that pervasively ornament both the walls of the burrows and the exterior of local crocodilian coprolites, it seems reasonable to regard these burrows as the result of coprophagy.

Acknowledgements. We are very pleased to acknowledge Scott Whittaker (National Museum of Natural History) who took the SEM image in Figure 3A. Luigi Folco (Università di Pisa) is also kindly acknowledged for his support during the FEI-SEM analyses. We would also like to sincerely thank Adrian Hunt and one anonymous reviewer for their constructive and skillfull reviews. Journal staff at Rivista Italiana di Paleontologia e Stratigrafia who helped move the manuscript through the publication process include the section Editor Lorenzo Rook, the Editors-in-Chief Lucia Angiolini and Fabrizio Berra, and the technical Editor Cristina Lombardo; thank you! This article was made possible by funding from the citizens of Calvert County, the County Board of Calvert County Commissioners, and the Clarissa and Lincoln Dryden Endowment for Paleontology at the Calvert Marine Museum. 
REFERENCES

Bruthansová J. \& Kraft P. (2003) - Pellets independent of or associated with Bohemian Ordovician body fossils. Acta Palaeontologica Polonica, 48(3): 437-445.

Cameron C.B. (2002) - Particle retention and flow in the pharynx of the enteropneust worm Harrimania planktophilus: The filter-feeding pharynx may have evolved before the chordates. The Biological Bulletin, 202(2): 192-200.

Carnevale G., Godfrey S.J. \& Pietsch T.W. (2011) - Stargazer (Teleostei, Uranoscopidae) cranial remains from the Miocene Calvert Cliffs. Maryland, U.S.A. (St. Marys Formation, Chesapeake Group). Journal of Vertebrate Paleontology, 31(6): 1200-1209.

Carnevale G. \& Godfrey S.J. (2018) - Miocene bony fishes of the Calvert, Choptank, St. Marys, and Eastover Formations, Chesapeake Group, Maryland and Virginia. Smithsonian Contributions to Paleobiology, 100: 161-212.

Chin K. (2007) - The paleobiological implications of herbivorous dinosaur coprolites from the Upper Cretaceous Two Medicine Formation of Montana: why eat wood? Palaios, 22(5): 554-566.

Chin K. \& Gill B.D. (1996) - Dinosaurs, dung beetles, and conifers: Participants in a Cretaceous food web. Palaios, 11: 280-285.

Clark W.B., Shattuck G.B. \& Dall W.H. (Eds.) (1904) - The Miocene Deposits of Maryland. Maryland Geological Survey, Miocene, 1: xxxiii-cxxxvii.

Cooper C.L. (1935) - Ammonium chloride sublimate apparatus. Journal of Paleontology, 9(4): 357-359.

de Verteuil L. \& Norris G. (1996) - Miocene dinoflagellate stratigraphy and systematics of Maryland and Virginia: Micropaleontology, 42, Supplement: 1-172.

Domning D.P. (2018) - Fossil Sirenia (Mammalia) of the Miocene Chesapeake Group, Eastern United States. Smithsonian Contributions to Paleobiology, 100: 241-265.

Feldman R.M. (1989) - Whitening fossils for photographic purposes. In: Feldman R.M. (Ed.) - Paleotechniques. The Paleontological Society Special Publication, 4: 342-346.

Godfrey S.J. (Ed.) (2018) - The geology and vertebrate paleontology of Calvert Cliffs. Smithsonian Contributions to Paleobiology, 100: 1-274.

Godfrey S.J. \& Smith J. (2010) - Shark-bitten vertebrate coprolites from the Miocene of Maryland. Naturwissenschaften, 97(5): 461-467.

Godfrey S.J. \& Carnevale G. (2020) - A new cobia (Teleostei, Rachycentridae) species from the Miocene St. Marys Formation along Calvert Cliffs, Maryland, USA. Journal of Paleontology, doi: 10.1017/jpa.2020.107.

Godfrey S.J., Alford A., Collareta A. \& Weems R.E. (2020) - A Paleocene vertebrate-bitten crocodilian coprolite from Liverpool Point, Maryland, USA. Neues Jabrbuch für Geologie und Paläontologie-Abhandlungen, 296(3): 237-244.

Häntzschel W., El-Baz F. \& Amstutz G.C. (1968) - Coprolites: an annotated bibliography. Geological Society of America Memoir, 108: 1-132.

Hunt A.P., Lucas S.G. \& Klein H. (2018) - Late Triassic non- marine vertebrate and invertebrate trace fossils and the pattern of the Phanerozoic record of vertebrate trace fossils. In: Tanner L.H. (Ed.) - The Late Triassic World, Topics in Geobiology, 46: 447-543. Springer Verlag, New York (NY).

Kent B.W. (2018) - The cartilaginous fishes (chimaeras, sharks and rays) of Calvert Cliffs, Maryland, USA. In: Godfrey S.J. (Ed.) - Geology and Vertebrate Paleontology of Calvert Cliffs. Smithsonian Contributions to Paleobiology, 100: 45-160.

Kidwell S.M. (1984) - Outcrop features and origin of basin margin unconformities in the lower Chesapeake Group (Miocene), Atlantic Coastal Plain. In: Schlee J.S. (Ed.) - Interregional Unconformities and Hydrocarbon Accumulation. American Association of Petroleum Geologists Memoir, 36: 37-58.

Kidwell S.M. (1988) - Reciprocal sedimentation and noncorrelative hiatuses in marine-paralic siliciclastics: Miocene outcrop evidence. Geology, 16: 609-612.

Kidwell S.M. (1989) - Stratigraphic condensation of marine transgressive records: Origin of major shell deposits in the Miocene of Maryland. The Journal of Geology, 97: $1-24$.

Kidwell S.M. (1997) - Anatomy of extremely thin marine sequences landward of a passive-margin hinge zone: Neogene Calvert Cliffs succession, Maryland, U.S.A. Journal of Sedimentary Research, 67: 222-240.

Kidwell S.M., Powars D.S., Edwards L.E. \& Vogt P.R. (2015) - Miocene stratigraphy and paleoenvironments of the Calvert Cliffs, Maryland. The Geological Society of America Field Guide, 40: 231-279.

Knaust D. (2008) - Balanoglossites Magdefrau, 1932 from the Middle Triassic of Germany: part of a complex trace fossil probably produced by burrowing and boring polychaetes. Paläontologische Zeitschrift, 82: 347-372.

Knaust D. (2020) - Invertebrate coprolites and cololites revised. Papers in Palaeontology, 6(3): 385-423.

Kuo M. \& Bolton M. (2013) - The nature and origin of deep ocean clay crust from the Gulf of Guinea. Geotechnique, 63(6): 500-509.

Milàn J., Rasmussen B.W. \& Bonde N. (2012) - Coprolites with prey remains and traces from coprophagous organisms from the Lower Cretaceous (Late Berriasian) Jydegaard Formation of Bornholm, Denmark. New Mexico Museum of Natural History and Science Bulletin, 57: 235-240.

Moore H.B. (1931) - The specific identification of faecal pellets. Journal of the Marine Biological Association (New Series), 17(2): 359-365.

Perez V.J., Godfrey S.J., Kent B.W., Weems R.E. \& Nance J.R. (2019) - The transition between Carcharocles chubutensis and Carcharocles megalodon (Otodontidae, Chondrichthyes): lateral cusplet loss through time. Journal of Vertebrate Paleontology, 38(6): e1546732.

Poag C.W. (1979) - Stratigraphy and depositional environments of Baltimore Canyon Trough. American Association of Petroleum Geologists Bulletin, 63: 1452-1466.

Shattuck G.B. (1904) - Geological and paleontological relations, with a review of earlier investigations. In: Clark 
W.B., Shattuck G.B., and Dall W.H. (Eds.) - The Miocene of Maryland: 71-93. Maryland Geological Survey, John Hopkins University Press, Baltimore (MD).

Shelburne E.C.H. \& Thompson A.C. (2016) - Specimen whitening: An assessment of methods of ammonium chloride smoke removal. Collection Forum, 30(1): 63-72.

Tapanila L., Roberts E.M., Bouare M.L., Sissoko F. \& O’Leary M.A. (2004) - Bivalve borings in phosphatic coprolites and bone, Cretaceous-Paleogene, northeastern Mali. Palaios, 19(6): 565-573.

Toom U., Vinn O. \& Hints O. (2019) - Ordovician and Silurian ichnofossils from carbonate facies in Estonia: a collection-based review. Palaeoworld, 28: 123-144.

Toom U., Vinn O., Isakar M., Madison A. \& Hints O. (2020) - Small faecal pellets in Ordovician shelly fossils from Estonia, Baltoscandia. Estonian Journal of Earth Sciences, 69(1): 1-19.

Urata M., Iwasaki S. \& Ohtsuka S. (2012) - Biology of the swimming acorn worm Glandiceps hacksi from the Seto Inland Sea of Japan. Zoological Science, 29(5): 305-310.

Vogt P.R. \& Eshelman R.E. (1987) - Maryland's Cliffs of Calvert: A fossiliferous record of mid-Miocene inner shelf and coastal environments. In: Roy D.C. (Ed.) - Geological Society of America Centennial Field Guide, Northeastern Section: 9-14. GSA, Boulder (CO).

Vogt P., Eshelman R.E. \& Godfrey S.J. (2018) - Calvert Cliffs: eroding mural escarpment, fossil dispensary, and paleoenvironmental archive in space and time. Smithsonian Contributions to Paleobiology, 100: 3-44.

Vokes H.E. (1957 [1968 reprint]) - Miocene Fossils of Maryland. Maryland Geological Survey Bulletin, 20: 1-85.

Ward. L.W. (1992) - Molluscan biostratigraphy of the Miocene middle Atlantic coastal plane of North America. Virginia Museum of Natural History, Memoir, 2: 1-159.

Ward L.W. \& Andrews G.W. (2008) - Stratigraphy of the Calvert, Choptank, and St. Marys Formation (Miocene) in the Chesapeake Bay area, Maryland and Virginia. Virginia Museum of Natural History Memoir, 9: 1-60.

Ward L.W. \& Strickland G.L. (1985) - Outline of Tertiary stratigraphy and depositional history of the U.S. Atlantic Coastal Plain. In: Poag C.W. (Ed.) - Geological Evolution of the United States Atlantic Margin: 87-123. Van Nostrand Reinhold, New York (NY).

Weems R.E. (2018) - Crocodilians of the Calvert Cliffs. Smithsonian Contributions to Paleobiology, 100: 213-240.

Weems R.E. \& George R.A. (2013) - Amphibians and nonmarine turtles from the Miocene Calvert Formation of Delaware, Maryland, and Virginia (USA). Journal of Paleontology, 87(4): 570-588.

Wetmore A. (1943) - The occurrence of feather impressions in the Miocene deposits of Maryland. The Auk, 60: 440441. 
